\title{
SOIL DRYNESS AND ITS EFFECT ON TOXIC COPPER MOBILITY
}

\author{
Hossam Altaher $^{1,2}$, Andrea Dietrich ${ }^{2}$, and John Novak ${ }^{2}$ \\ 1 Department of Chemical Engineering Technology, Yanbu Industrial College, Saudi \\ 2 Department of of Civil and Env. Eng., Faculty of Eng., Virginia Tech, Blacksburg, USA
}

\begin{abstract}
Copper is applied to many crops as a fungicide/bactericide, including plasticulture tomato growing operations. Therefore, a laboratory study was undertaken to determine if this agricultural copper can migrate in soil and to determine the mechanisms that account for the movement through soil to the subsurface. Total Organic Carbon (TOC), dryness and its temperature cycle, and water content of the soil were selected for study. These factors were investigated in both batch and continuous flow (column) processes. Results demonstrated that copper mobility through soil columns was associated with TOC mobility, and soil drying had a major effect on both copper and TOC mobility. The concentration of copper eluted from columns containing dried soils was as high as $120 \mu \mathrm{g} / \mathrm{l}$ copper and $150 \mathrm{mg} / \mathrm{l}$ TOC. The copper and TOC concentrations from dried soils were very high compared with those containing wet soils. The extent of dryness was found to affect mobility. A first-flush-pattern for both copper and TOC was observed in all columns studies.
\end{abstract}

Keywords: Copper, Toxic, Mobility, Dryness, Pollution, Soil

\section{INTRODUCTION}

Many contaminants have been reported as sources of pollution of soil and ground water, e.g., waste water and solid wastes from industrial production, fertilizers and pesticides. Agriculture practices constitute significant non-point sources of metals. The main sources of this type of pollution are pesticides, impurities in fertilizers, wood preservatives and corrosion of metal objects like metal roofs and fences [1]. Although amount of copper applied to simulated plasticulture tomato fields was found to remain in the field sorbed to the soil, the amount of copper leaving the tomato field in the runoff and groundwater was sufficient to cause aquatic toxicity. "Following rainfall, $99 \%$ of the applied copper was found to remain on the field sorbed to the soil. Of the copper leaving the agricultural field, $82 \%$ was found in the runoff. The remaining copper, $18 \%$, leached through the soil and entered the ground water. The average copper concentrations in ground water samples were $312 \pm 198 \mu \mathrm{g} / \mathrm{l}$ as total copper" [2]. Aqueous and sediment copper concentrations were measured in agricultural and non-agricultural watersheds and were found higher for the former use [3]. The dissolved copper concentrations in runoff from tomato plasticulture fields were as high as $238 \mu \mathrm{g} / \mathrm{l}$, whereas the runoff concentrations from other land uses were less than $5 \mu \mathrm{g} / \mathrm{l}$ [3]. The mobility of heavy metals depends on their chemical speciation, which in turn is related to the chemical properties of soil. For example, in some types of soil the presence of carbonates effectively immobilizes cadmium 
and copper by providing an adsorbing surface or by buffering the $\mathrm{pH}$ [4]. Soil parameters, such as $\mathrm{pH}$, organic carbon content, iron and manganese oxide content and total metal content affect the distribution of copper and cadmium among different soil fractions [5].

The mobility of heavy metals, including copper, may be enhanced by the formation of inorganic complexes. Chloride ions, for example, can form complexes with many cations such as $\mathrm{Cd}$ (II), $\mathrm{Hg}$ (II), PB (II), $\mathrm{Zn}$ (II) and $\mathrm{Cu}$ (II) [6].

The important role of organic matter in the retention and behavior of copper was discussed. It was reported that both humic and fulvic acids as two ligands for copper (II) binding with the fulvic acids being the more soluble than humic acids. They also reported simple aliphatic acids, amino acids and aromatic acids as chelating agents for copper (II) [7].

Igloria et al. [8] indicated the possibility of formation of complexes between heavy metals and organic matter colloids in solutions, as well as those attached to soil surfaces. Sposito [9], on the other hand, claimed that the effect of these colloids might retard metals transport. Ma et al. [10] suggested that the chemical speciation of the metals determined metal behavior and mobility in the environment.

\section{OBJECTIVES}

Gallagher et al. [2] found that copper applied to agricultural fields readily percolated through the soil and reached concentrations of about $300 \mu \mathrm{g} / \mathrm{l}$ total copper and $200 \mu \mathrm{g} / \mathrm{l}$ dissolved copper in the leachate. The objective of this research was to determine the mechanism(s) of copper mobility through different soil horizons obtained from the Eastern Shore of Virginia. Identifying the major mechanism(s) could help to control copper mobility in these soils and reduce the potential for damage to the aquatic environment in this region by improving agricultural practices.

\section{MATERIALS AND METHODS}

The soil used for this study was a Bojac sandy loam. It was obtained from an undisturbed lot in Parksley, VA. Grass and roots were removed from the top layer of the soil. Ahorizon soil was obtained from depths ranging from 0 to 18 inches. The soil had a strong brown color and a sandy loam or loam texture. B-horizon soil was obtained from below the A-horizon. The B-horizon soil at this depth was obviously color differentiated from the Ahorizon. The color of B-horizon soil was light brown compared with dark brown for the Ahorizon soil. The soil was sieved and dried before being used for study; only the fraction less than $2 \mathrm{~mm}$ was used. The moisture content for the wet soil was $13 \%$ unless otherwise mentioned. The moisture content after drying was $2 \%$. In general air-dried soil was used throughout this research ( $2 \%$ moisture content) unless otherwise mentioned.

All chemicals and reagents used for this study were analytical grade or trace metal grade. Nanopure $^{\circledR}$ water was used for all reagent preparation and dilutions unless otherwise specified. The copper solutions were prepared by diluting copper reference solution (1 $\mathrm{mg} / \mathrm{ml}$ ) obtained from Fisher Scientific. All plastic ware and glassware used in experiments were soaked in $10 \%$ trace metal grade nitric acid for at least 8 hours, rinsed with distilled water three times followed by rinsing with Nanopure $^{\circledR}$ water three times. The glassware (except for volumetric flasks) was oven dried at $102{ }^{\circ} \mathrm{C}$; plastic ware and volumetric glassware were air-dried. The containers used for batch adsorption processes were tested for 
copper adsorption by shaking copper solution in 8 glass conical flasks and 6 plastic bottles for 24 hours. Copper was not absorbed or released by the containers used in these experiments. Clear, rigid PVC columns used for continuous study were purchased from United States Plastic Corp. They were not tested for copper adsorption but the information obtained from the manufacturer indicated that this material does not adsorb copper and it is not affected by acidity. Total organic carbon (TOC) was measured on samples acidified with phosphoric acid to less than $\mathrm{pH} 2$ and then purged with oxygen for five minutes. TOC was then measured by the UV assisted persulfate-oxidation method with infrared detection of the evolved carbon dioxide on a Dohrmann Carbon Analyzer DC-80.

The dissolved copper was measured according to Standard Methods for the Examination of Water and Wastewater, number 3030B (APHA 1995) using a Perkin Elmer703 Atomic Absorption Spectrophotometer (flame atomic absorption, FAA). The wavelength used was $324.8 \mathrm{~nm}$ with a $0.7 \mathrm{~nm}$ slit setting; the range was $100-5000 \mu \mathrm{g} / \mathrm{l}$ copper. For copper concentrations below $100 \mu \mathrm{g} / \mathrm{l}$, a Perkin Elmer Zeeman 5100 HGA Graphite Furnace Atomic Absorption spectrophotometer (GFAA) was used.
All the samples for copper analysis were acidified with $1: 1 \mathrm{HNO}_{3}$ solution to less than $\mathrm{pH} 2$ and stored at $4{ }^{\circ} \mathrm{C}$. Some soil samples

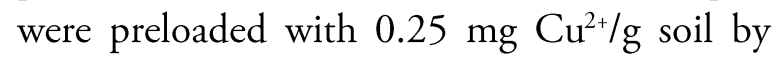
adding $100 \mathrm{~g}$ of soil to a copper solution containing $25 \mathrm{mg}$ of $\mathrm{Cu}^{2+}$. The soil solution was stirred for 24 hours followed by drying at $105 \pm 3{ }^{\circ} \mathrm{C}$. The soil was crushed and sieved through $2 \mathrm{~mm}$ sieves.

Dissolved copper losses during filtration were investigated. Three samples of copper nitrate solution $(400 \mu \mathrm{g} / \mathrm{l}$ and $\mathrm{pH}$ 6) were passed through $0.45 \mu \mathrm{m}$ membrane filters from different companies and through G6 filters. The initial and final concentrations of copper were measured. A minute amount of copper loss was measured for the $0.45 \mu \mathrm{m}$ Gelman membrane filters whereas very high losses (65\%) were detected for the G6 filters. However other filter papers had showed noticeable adsorption towards copper. For this reason Gelman $0.45 \mu \mathrm{m}$ membrane filters were used for all filtration processes. The soil used in this research was analyzed for organic matter $(\mathrm{OM}), \mathrm{pH}$, and selected metals $(\mathrm{Ca}$, $\mathrm{Mg}, \mathrm{P}, \mathrm{K}, \mathrm{Zn}, \mathrm{Mn}$ and $\mathrm{Fe}$ ) in the Soil Testing \& Plant Analysis Laboratory, Virginia Polytechnic Institute \& State University. Table 1 presents the soil analysis.

Table 1: Physical ANd Chemical Properties of THE SANDy LoAm SOIL

\begin{tabular}{|c|c|c|c|c|c|c|c|c|c|}
\hline \multirow{2}{*}{ Sample } & \multirow{2}{*}{$\mathrm{pH}$} & \multirow{2}{*}{$\% \mathrm{OM}$} & \multicolumn{7}{|c|}{ Chemical Concentration (ppm) } \\
\cline { 5 - 10 } & & & $\mathrm{P}$ & $\mathrm{K}$ & $\mathrm{Ca}$ & $\mathrm{Mg}$ & $\mathrm{Zn}$ & $\mathrm{Mn}$ & $\mathrm{Fe}$ \\
\hline Sand & 5.6 & 0.01 & 0.94 & 2.78 & 52.3 & 10.02 & 0.21 & 0.64 & 1.83 \\
\hline B-horizon & 7.4 & 1.09 & 4.36 & 23 & 1335 & 40.48 & 1.08 & 21.89 & 6.32 \\
\hline A-horizon & 6.7 & 3.29 & 10.3 & 57.3 & 1735 & 96.24 & 3.72 & 38.05 & 7.51 \\
\hline
\end{tabular}




\subsection{EFFECT OF DRYING METHOD ON COPPER ADSORPTION}

An experiment was conducted to study the effect of soil drying method on the sorptive capacity of the soil. A-horizon Bojac sandy loam soil samples were dried in three ways. The first sample was oven dried at $105 \pm 3{ }^{\circ} \mathrm{C}$ for 2 hours. The second sample was placed in a tray at a thickness of about $2 \mathrm{~cm}$, and then air dried in equilibration with room humidity for three days. The third sample was autoclave-dried for 2 hours in an Amsco Scientific SG-116 Autoclave (Eagle/century series). The temperature was adjusted to $132^{\circ} \mathrm{C}$ and the pressure was 30 psi. A $357 \mu \mathrm{g} / \mathrm{l}$ and $\mathrm{pH} 6$ copper solutions was prepared. Duplicates of each type of soil (air-dried, oven dried and autoclave dried) were used. A 100 $\mathrm{ml}$ of copper solution was added to $2.1 \mathrm{~g}$ soil sample for each test. The solutions were shaken for 24 hours, filtered through $0.45 \mu \mathrm{m}$ filters and the final copper concentration was measured.

\subsection{EFFECT OF PULSE INPUT ON COPPER DESORPTION}

The purpose of this experiment was to study the possible copper desorption from Bhorizon soil following the step addition of a copper nitrate solution. A mixture of dry Bhorizon soil and sand was prepared to reach a ratio of 7:3, soil: sand respectively. Twenty grams of this soil mixture was placed into glass column (internal diameter $3 \mathrm{~cm}$ ) to a height of $4 \mathrm{~cm}$. A copper nitrate solution at $\mathrm{pH} 6$ was added as a step input $(100 \mathrm{ml}$ for each addition for a total amount of 6 litres). The volume of the copper solution added was equivalent to about 344 pore volumes. The amount of copper added was equivalent to $0.24 \mathrm{mg} / \mathrm{g}$, and should have exceeded the adsorption capacity of that type of soil based on adsorption isotherm data.

\subsection{COMPARISON OF COPPER MOBILITY THROUGH BOTH WET AND DRY A- AND B-HORIZON SOILS}

This experiment was conducted to compare copper mobility through wet and dry soils. The first set of experiments was conducted using the wet (13\% moisture content) fresh soil packed into stoppered polyethylene columns (see Fig. 1). Glass wool was placed over the stopper to prevent the loss of soil. Columns were packed with either $300 \mathrm{~g}$ (wet weight) of fresh A-horizon soil or fresh Bhorizon soil. The soil was added in $50 \mathrm{~g}$ fractions followed by tapping the column to achieve consolidation. The soil columns were stored at $4{ }^{\circ} \mathrm{C}$ until the beginning of the experiment to minimize biological activity. A volume of $400 \mathrm{ml}$ of $500 \mu \mathrm{g} / \mathrm{l} \mathrm{Cu} \mathrm{Cu}^{2+}(\mathrm{pH} \mathrm{6})$ was added to each column as pulse input.

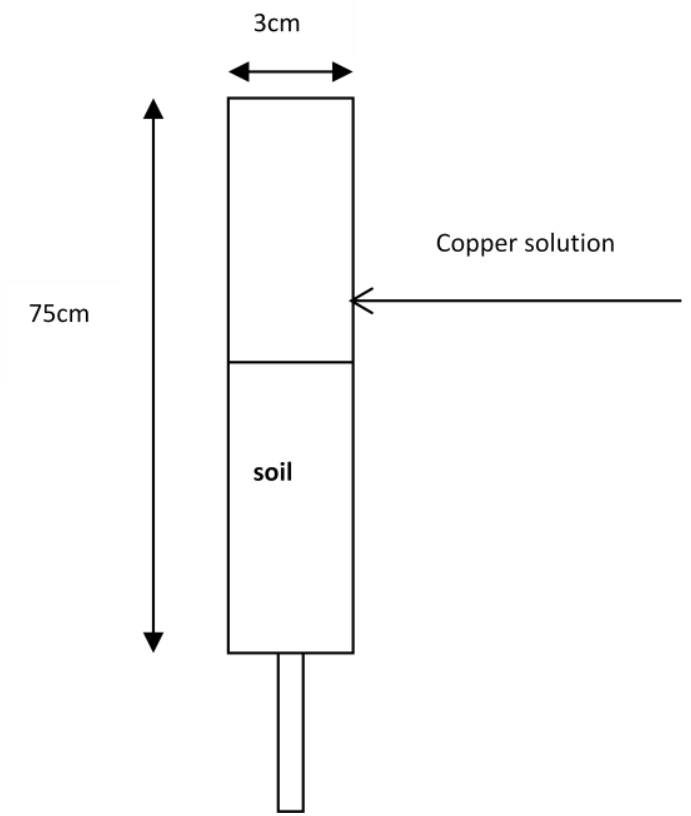

Fig. 1. Schematic diagram of the column used for copper mobility study

Two other columns with the same dimensions were filled with $300 \mathrm{~g}$ of dry A- and Bhorizon soils, respectively. The soil was airdried for 2 weeks, crushed and passed through $2 \mathrm{~mm}$ sieve, and loaded into the column. The soil column was tapped until no further consolidation was noticed. A volume of 400 
$\mathrm{ml}$ of the $500 \mu \mathrm{g} / \mathrm{l} \mathrm{Cu}^{2+}$ was added to the column. Effluent samples from all four columns were collected and analyzed for copper and TOC.

\subsection{EFFECT OF SOIL MOISTURE CONTENT ON COPPER MOBILITY}

It was observed during preliminary experiments that there was some difference in the mobility of copper in soil columns containing dried soil compared to wet soil. Therefore, an experiment was designed to study the effect of the soil moisture content on copper mobility. Dry A-horizon soil was preloaded with $0.25 \mathrm{mg} / \mathrm{g}$ copper using the method described previously. The soil was mixed with sand (7 parts soil to 3 parts sand) to increase the rate of water flow. Water was added to provide water content of $13 \%$, which was the percentage found in the fresh soil obtained from the field. The prepared wet soil was split into $20 \mathrm{~g}$ fractions and either oven dried at $55{ }^{\circ} \mathrm{C}$ or air-dried at room temperature to achieve different water contents. Glass columns $(38 \mathrm{~cm}$ length and $3 \mathrm{~cm}$ internal diameter) were packed to $4 \mathrm{~cm}$ soil height with these fractions. One hundred $\mathrm{ml}$ of Nanopure ${ }^{\circledR}$ water at $\mathrm{pH} 6$ was added to each column. Effluent samples were collected and analyzed for copper and TOC.

\subsection{DRY SOIL VERSUS WET SOIL AND THE EFFECT ON COPPER DESORPTION}

This experiment was designed to mimic seasonal variation from wet to dry soil and to determine the influence of moisture content on copper desorption from the soil preloaded with $0.25 \mathrm{mg} / \mathrm{g}$ copper. Two columns were packed with $20 \mathrm{~g}$ of a mixture of dry $(2 \%$ moisture content) A-horizon soil and sand (7:3, weight ratio). The columns were tapped several times until the soil height in the columns became $4 \mathrm{~cm}$. One hundred $\mathrm{ml}$ aliquots of Nanopure ${ }^{\circledR}$ water ( $\mathrm{pH}$ 6) were added to each column and effluent samples were collected. Water was allowed to gravity drain from the two columns, and then the columns were allowed to stand for 15 hours. One of the columns was also placed in an oven at $70{ }^{\circ} \mathrm{C}$ for 2 hours to provide additional drying. After the drying periods, another $100 \mathrm{ml}$ portion of Nanopure ${ }^{\circledR}$ water was added to each column and effluent samples were collected. Another cycle of drying in the oven was applied to the same column that had been oven-dried previosly while the other column was left in the open atmosphere. A third set of $100 \mathrm{ml}$ portions of Nanopure ${ }^{\circledR}$ water were applied to the columns. Effluent samples were collected and analyzed for copper.

\section{RESULTS AND DISCUSSION}

\subsection{SORPTION/DESORPTION OF COPPER FROM SOIL IN COLUMN}

Based on the batch data, when adding a copper solution to a soil column, it was expected that little copper would elute from the column until saturation was reached and then the influent concentration would be equal to the effluent concentration. However, in this experiment, the copper concentration discharged from a column packed with dry Bhorizon soil fed with a copper solution of 600 $\mu \mathrm{g} / \mathrm{l}$ was monitored to determine if the copper was retained by the soil and to determine the capacity of the soil for copper under continuous loading conditions. The results in Figure 2 indicate that the saturation capacity of the soil for copper was not reached, even though the batch adsorption data suggested the system should have been at capacity.

Because the addition of excess copper did not result in breakthrough, it is clear that the batch adsorption data was not indicative of the actual sorption capacity of the soil. The amount of copper applied to the column was 
5 times the predicted batch capacity that was obtained in preliminary experiments.

A possible explanation of the copper behavior is its binding to the organic substances on the soil [11]. Part of these organic substances were mobilized and flushed from the column. Data in Fig.2. illustrates the volume eluted from the column against copper and TOC concentrations. This data indicates that the mobility of copper and TOC elution follow similar patterns. The organic matter that remained with the soil retained some of the copper thereby hindering its mobility.

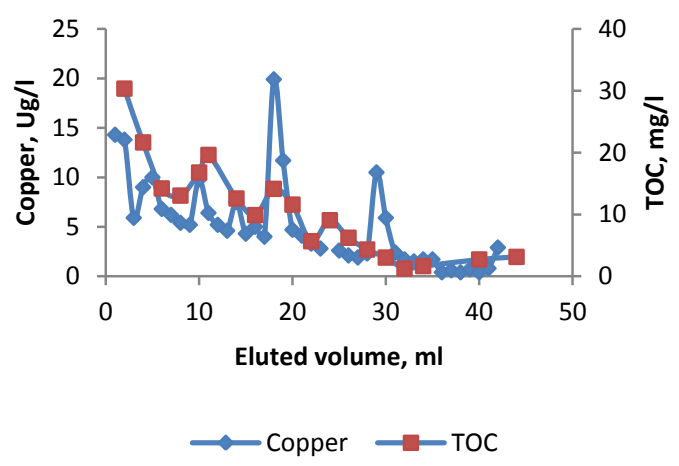

Fig. 2. Copper mobility though B-horizon soil with excessive addition of copper nitrate solution of $\mathrm{pH} 6$ and $600 \mu \mathrm{g} / \mathrm{Cu}$.

According to this mechanism, once the mobile TOC fraction has been flushed from the soil, the soil would have a very large capacity for additional copper. This mechanism was suggested by batch isotherm data where the copper in solution was associated with solution TOC.

Another possibility is that physical filtration might be occurring. The copper combines with organic substances and possibly with other constituents of the soil. The fraction of these particles that has a size smaller than the interstitial positions will pass through the soil and will be washed out. Large particle sizes will be trapped throughout the soil column. This later scenario is strengthened by comparing the column results to those obtained from batch processes. When the soil solution from the batch isotherm studies was filtered after reaching equilibrium, the copper concentration was found to be low. When analyzing the solution without filtration (but with 2 days of settling) the concentration of the copper was found to be much higher, which indicates that copper is attached to organic particles or colloids in solution.

In a study of the dissolved organic carbon (DOC) mobility, Jardine et al. [12] noticed a higher mobility of DOC through large pores compared to small pores. They considered these small pores as a sink for DOC. In other studies [13], the high adsorption capacity of lower soil horizons for DOC compared with upper soil horizons was reported. Experimental results from this study indicate the high adsorption capacity of the B-horizon soil to copper. The reason may be an association of copper and organic substances followed by binding of the formed compounds to soil. Di Palma et al. [14] agreed with these results. They found in their field study that one type of DOC enhanced the mobility of copper while the other type did not affect mobility. It is likely that the type of organic matter that did not affect the mobility was sorbed on the soil surface or filtered out.

\subsection{MOBILITY OF COPPER}

\subsubsection{Effect of soil dryness on copper mobility}

This portion of the study was conducted to study the effect of soil drying on copper mobility. Figures 3, 4, 5 and 6 show the results obtained from this experiment, and illustrate the effect of soil dryness on copper mobility. The maximum copper concentration in the effluent from the column containing wet B-horizon soil was $11 \mu \mathrm{g} / \mathrm{l}$ and the average concentration was $1 \mu \mathrm{g} / \mathrm{l}$. The copper concentration eluted from the dry-soil column reached a maximum of $70 \mu \mathrm{g} / \mathrm{l}$ and 
an average concentration of $20 \mu \mathrm{g} / \mathrm{l}$. The same effect was observed for TOC. The maximum TOC for the wet soil was around $15 \mathrm{mg} / \mathrm{l}$ and the average value was around 7 $\mathrm{mg} / \mathrm{l}$ whereas for the dry soil the maximum TOC was $90 \mathrm{mg} / \mathrm{l}$ and the average value was $30 \mathrm{mg} / \mathrm{l}$.

The copper and TOC values for A-horizon soils were higher than those for B-horizon. The average copper concentration eluted from the wet soil was $10 \mu \mathrm{g} / \mathrm{l}$, whereas the maximum copper concentration eluted from dry A-horizon soil was $120 \mu \mathrm{g} / \mathrm{l}$ with an average of $40 \mu \mathrm{g} / \mathrm{l}$. The maximum TOC eluted from wet A-horizon soils was $15 \mathrm{mg} / \mathrm{l}$ and the average was $10 \mathrm{mg} / \mathrm{l}$. The maximum TOC eluted from the dry soil was $150 \mathrm{mg} / \mathrm{l}$ and the average was $50 \mathrm{mg} / \mathrm{l}$. This suggests that the dryness of the soil increased the mobility of TOC and copper. The relationship between copper mobility and TOC mobility can be clearly seen for both dry soil and wet soil.

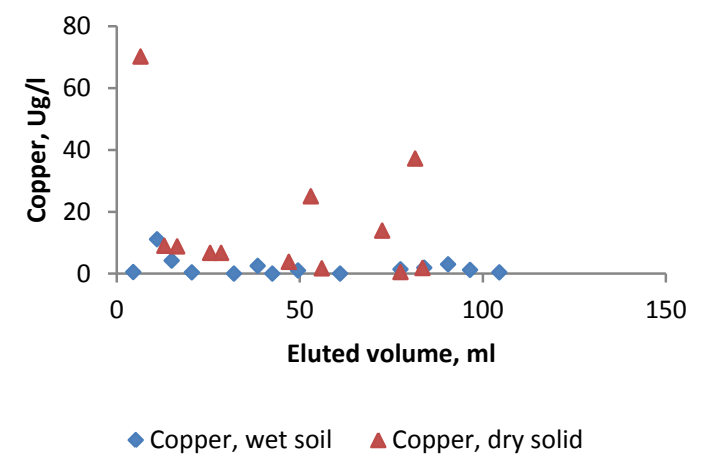

Fig. 3. Mobility of copper through columns of wet and airdried B-horizon soil. The concentration of copper solution was $500 \mu \mathrm{g} / \mathrm{l}$ and its $\mathrm{pH}$ was 6.

The data also show that the soil with the highest organic matter content (A-horizon) was much more sensitive to drying than the lower organic content B-horizon soil. The relationship between TOC and copper could be seen in all the studies. Every increase in the concentration of copper was associated with a corresponding increase in TOC.

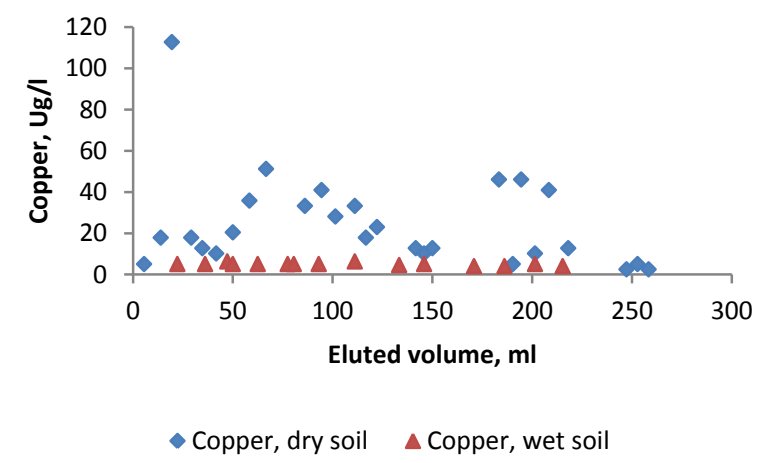

Fig.4. Mobility of copper through columns of wet and airdried A-horizon soil. Concentration of copper solution was $500 \mu \mathrm{g} / \mathrm{l}$ and its $\mathrm{pH}$ was 6 .

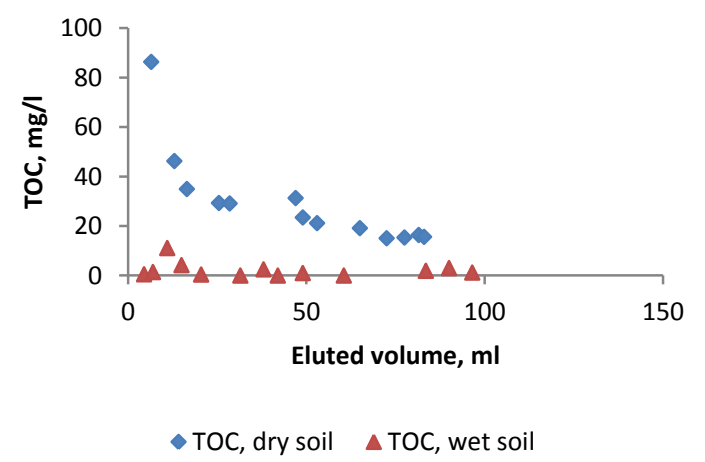

Fig. 5. TOC mobility through wet and air-dried B-hrizon soil. The concentration of copper nitrate solution was $500 \mu \mathrm{g} / \mathrm{l}$ and its $\mathrm{pH}$ was 6 .

Some researchers had different results. Jardine et al. [12] indicated that the mobility of organic carbon in the form of DOC was greater during wet events. On the other hand, Borken et al. [15] observed that the mobility of DOC increased after the soil was dried at different temperatures. They attributed this to modified microbial activity. The results of Noak et al. [16] agree with Borken et al. They suggested that particle interaction due to dryness was a possible effect that enhanced the physical filtration of these particles. So in summary, both the moisture and organic content of the soil play an important role in organic carbon and copper mobility. 
As illustrated in the soil analysis (Table 1), the organic carbon content of A-horizon soil is higher than that of B-horizon soil.

This organic carbon maybe the reasons for the higher copper concentration in the effluent from the A-horizon column even without drying of this soil. This argument is strengthened by the data observed in Figures 5 and 6. These two curves illustrate the mobility of TOC through dried A-horizon soil and dried B-horizon soil, respectively.

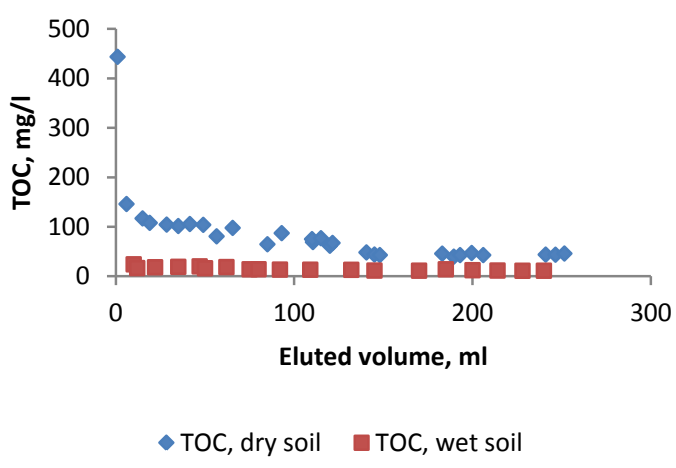

Fig.6. TOC mobility through wet and air-dried A-horizon soli. Eluent was copper nitrate solution of concentration 500 $\mu \mathrm{g} / \mathrm{l}$ and its $\mathrm{pH}$ was 6 .

The concentration of TOC flushed out in dry A-horizon soil case is about twice that value for B-horizon. As indicated in the Figures 5 and 6 , the base concentration of the flushed TOC from A-horizon is around $50 \mathrm{mg} / \mathrm{l}$ where that of B-horizon is $20 \mathrm{mg} / \mathrm{l}$. The concentration of copper flushed from the Ahorizon column is also more than twice the value for the B-horizon soil. As can be seen from Fig.2, whenever there was upward spike in the amount of copper eluted, this was accompanied by a spike in the TOC. These explanations agree with suggestions by Rigol et al. [17] in a study of mobility of radio cesium in organic soil. They found that the soil drying changed the sorption capacity of the soil considerably. They reasoned that the increase in desorption capacity was due to structural change in the solid phase due to drying. On the other hand, Noak et al. [16] mentioned a filtration effect by the soil matrix but they claimed that dryness would increase colloidal particle interaction forming large particle size, thus increasing the filtration effect. Burcar et al. [18] observed a similar effect for $\mathrm{NH}^{4+}-\mathrm{N}$ and $\mathrm{NO}^{3-}-\mathrm{N}$. They found that higher initial soil moisture resulted in the mobility of these two substances to greater soil depths.

\subsubsection{Effect of soil moisture content on copper mobility}

The goal of this experiment was to investigate the effect of soil moisture content on copper mobility. Figures 7 and 8 show that the water content of the soil primary affects the early stages of the elution process. Both the $2.6 \%$ and $6.5 \%$ moisture content soils eluted similar concentration of copper and TOC. The method of drying had some impact on the elution pattern as seen in Fig.8, At 6.5\% moisture, oven dried soil eluted more copper than the air dried samples. Butkus and Grasso [19] observed that the mobility of phosphate depends on the extent of dewatering of soil and its equilibrium $\mathrm{pH}$.

Also a first-flush-pattern appears clear in these experiments. Anderson et al. [20] observed that the highest copper levels in soils occur after rainfall following a long dry season. The first-flush-pattern is observed for both TOC and copper. After the first flush, the eluent concentration will be similar regardless of the initial soil water content. The reason may be that the soils become completely wet after the initial flush so the copper and TOC mobility is no longer influenced by prior moisture levels. García-Valcárcel and Tadeo [21] and Ponizovsky et al. [22] recorded also the effect of soil humidity on copper leaching.

Plots of copper versus TOC eluted from columns having different moisture contents (Fig.8) show the relationship between 
moisture content, TOC and copper. The dried soil produces both a Higher TOC and copper concentrations.

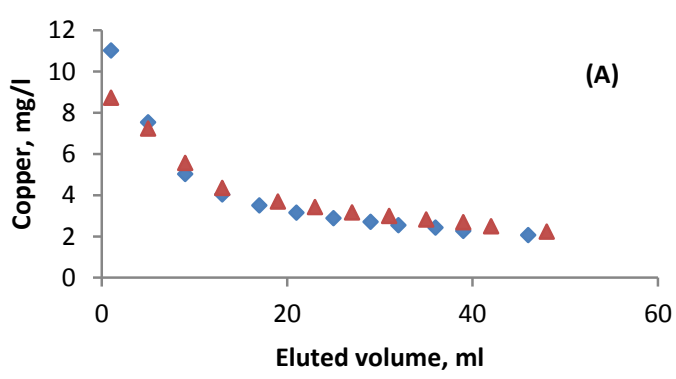

$\checkmark 2.5 \%$ moisture, air drying $\Delta 2.9 \%$ moisture, oven drying

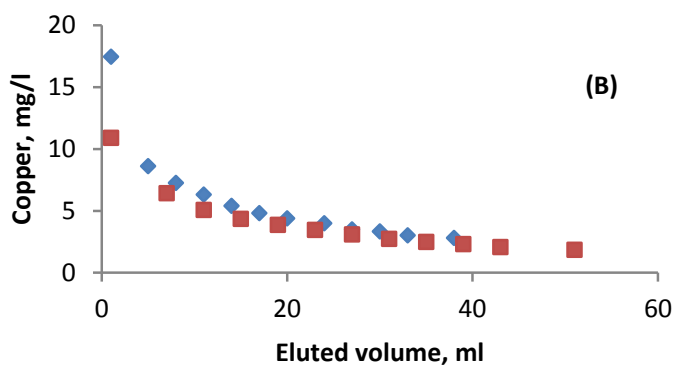

$\checkmark 6.5 \%$ moisture, air drying $\quad 6.2 \%$ moisture, air drying

Fig.7. Effect of moisture Content on copper mobility through A-horizon soil preloaded with $0.25 \mathrm{mg} \mathrm{Cu} / \mathrm{g}$ soil dried at $55^{\circ} \mathrm{C}$. Fig. (A) represents approximately $2.6 \%$ moisture and Fig. (B) represents approximately $6.5 \%$ moisture

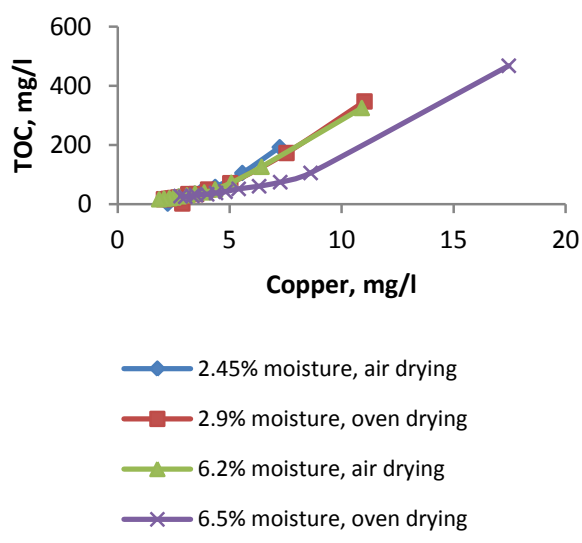

Fig. 8. Effect of moisture content on copper and TOC mobility through A-horizon soil preloaded with $0.25 \mathrm{mg}$ $\mathrm{Cu} / \mathrm{g}$ soil.

\subsection{ALTERNATE WET/DRY CYCLES}

The purpose of this experiment was to investigate short term drying on copper mobility through soil. This was achieved by comparing the copper concentration eluted from column containing soil that was dried for 2 hours after every addition of copper solution versus a soil that was not dried. The results of this experiment are depicted in Fig.9. The concentration of copper eluted after adding the first portion of copper solution was high. The first arrow indicates where drying occurred and a second portion of the copper solution was added. The second arrow indicates where drying the column for the second time occurred and adding the third portion of the copper solution. The flowstopped column did not show an increase in copper concentration after the flow was stopped because the column remained wet. The only difference between the two columns leading to these two curves was the drying cycle. Zhang and Xia [23] mentioned the leaching of copper due to climatic effects like rain. Dietrich et al. [3] demonstrated that dissolved copper continued to be present in runoff from copper-treated agricultural fields for months after the copper application and growing season ended.

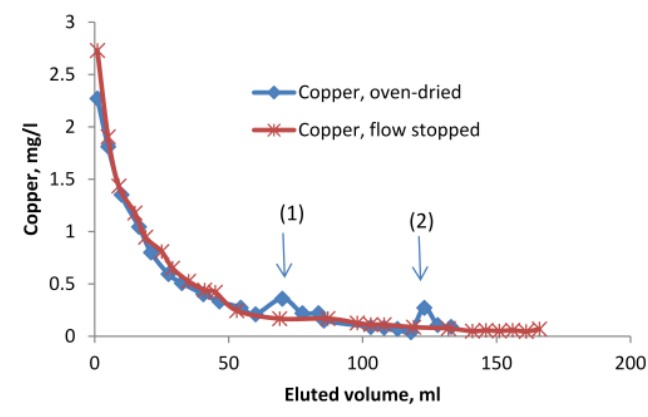

Fig. 9. Effect of drying on TOC mobility. A-horizon soil preloaded with $0.25 \mathrm{mg} / \mathrm{g}$ copper, nanopure water was used as eluent. For the oven dried column, the column was placed in oven at $70^{\circ} \mathrm{C}$ for 2 hours, then eluent flow continued. For flow stopped column, the eluent has ceased for 2 hours but the soil did not dry. The arrows indicate the points in the experiment when either the flow was stopped or the column was dried. 
Data in Fig.9. suggests that short periods of drying can increase copper desorption but that extended dryness will result in the discharge of larger amounts of TOC and sorbed copper.

\section{CONCLUSION}

Copper mobility through soil is mainly associated with TOC mobility. The mobility of TOC and copper are affected by several factors. Of these, the water content of the soil or drying pattern is most important. Drying the soil will increase the copper and TOC mobility which is possibly due to change in the structure of the organic substances present in the soil. Therefore, peaks of copper after rain events should be expected, especially after an extended dry period. The drying cycle or the drying temperature does not substantially affect copper mobility. For vertical transport, the mobility of copper through A-horizon soil is greater than that through B-horizon soil. Part of the copper escaping the A-horizon soil, may be sorbed on B-horizon soil. Other factors such as channeling and horizontal mobility should be taken into account when assessing the overall copper mobility.

\section{REFERENCES}

[1] Alloway, B.J., Soil Processes and the behavior of Metals. In: Heavy Metals in Soil, Edited by: B.J. Alloway, Blackie Academic \& Professional, London, 1995.

[2] Gallagher, D.L., K.M. Johnston and A.M. Dietrich, "Fate and Transport of Copper-Based Crop Protectants in Plasticulture Runoff and the Impact of Sedimentation as a Best Management Practice”, Water Research, Vol. 35(12), 2001, pp. 2984-94.

[3] Dietrich, A.M., D.L. Gallagher and K.A. Klawiter, "Inputs of Copper-Based Crop protectants to Coastal Creeks from Plasticulture Runoff”. J. American Water Research Assoc, Vol. 37(2), 2001, pp. 281-293.

[4] Dudley, L.M., J.E. McLean, T.H. Furst and J.J. Jurinak, "Sorption of Cadmium and Copper from an Acid Mine Waste Extract by Two Calcareous Soils: Column Study", Soil Sci., Vol.151(2) , 1991, pp. 121-135.

[5] Fic, M. and M.I. Schroter, "Batch Studies for the Investigation of the Mobility of the Heavy Metals $\mathrm{Cd}, \mathrm{Cr}, \mathrm{Cu}$ and $\mathrm{Zn}$ ”, Journal of Contaminated Hydrology, Vol. 4, 1989, pp. 69-78.

[6] Doner, H.E., Chloride as a Factor in Mobility of $\mathrm{Ni}$ (II), Cu (II) and Cd(II) in Soil”, Soil Sci. Soc. Am. J., Vol. 42, 1978.

[7] Howell, J.M. and J.M. Gawthorne, Copper in Animals and Man, Volume I\&II CRC Press, Inc. Boca Raton, Florida, 1987.

[8] Igloria, R.V., W.E. Hathhorn, Member, ASCE and D.R. Yonge,: "NOM and Trace Metal Attenuation During Storm-Water Infiltration", Journal of Hydrologic Engineering, Vol. 2(3), 1997, pp. 120-127.

[9] Sposito, G., "Sorption of Trace Metals by Humic Materials in Soils and Natural Water", RC Review in Env. Control, Vol.6(2) , 1986, pp. 193-229.

[10] Ma, Lena Q. and G.N. Rao, "Chemical Fractionation of Cadmium, Copper, Nickel and Zinc in Contaminated Soils”, J. Environ. Qual., Vol. 26, 1997, pp. 259-264.

[11] Salam D. and M. El-Fadel, "Mobility and Availability of Copper in Agricultural Soils Irrigated from Water Treated with Copper Sulfate Algaecide", Water, Air, \& Soil Pollution, Vol. 195(1-4), 2008, pp. 3-13.

[12] Jardine, P.M., G.V. Wilson, J.F. McKarthy, R.J. Luxmoore, D.L. Taylor and L.W. Zelazny, "Hydrogeochemical Processes Controlling the Transport of Dissolved Organic Carbon Through a Forestrd Hillslope", Journal of Contaminant Hydrology, Vol. 6, 1990, pp. 3-19.

[13] Jardine, P.M., N.L. Weber and J.F. McCarthy, "Mechanism of Dissolved Organic Carbon Adsorption on Soil”, Soil Sci. Soc. Am. J., Vol. 53, 1989, pp. 1378-1385.

[14] Di Palma I., P. Ferrantelli, C. Merli, E. Petrucci, and I. Pitzolu, "Influence of Soil Organic Matter on Copper Extraction from Contaminated Soil:, Soil \& Sediment Contamination, Vol. 16, 2007, pp. 323-335.

[15] Borken W., Y.J. Xu, R. Brumme and N. Lamersdorf, "A Climate Change Scenario for Carbon Dioxide and Dissolved Organic Carbon Fluxes from a Temperate Forest Soil: Drought 
and Rewetting Effects", Soil Sci. Soc. Am. J., Vol. 63, 1999, pp. 1848-1855.

[16] Noak, Angela G. Grant, Cameron D... Chittleborough and David J., "Colloid Movement Through Stable Soils of Low CationExchange Capacity", Environmental Science \& Technology. Vol. 34(12) , 2000, pp. 2490-2497.

[17] Rigol A., M. Vidal and G. Rauret, "Effect of the ilIonic Status and Drying on Radiocesiun Adsorption and Desorption in Organic Soils", Environ. Sci. Technol. Vol. 33, 1999, pp. 37883794.

[18] Burcar, S. Miller, W.W. Tyler, S.W. Blank, R R., "Moist and Dry Season Nitrogen Transport in Sierra Nevada Soils", Soil Science Society of America Journal, Vol. 61(6) , Nov-Dec. 1997, pp. 1774-1780.

[19] Butkus, MA and D. Grasso, "Impact of Phosphate Sorption on Water-Treatment Residual Surface Characteristics: Prelude to Reuse", Environmental Engineering and Science, Vol. 16(2) , 1999, pp. 117-130.

[20] Anderson, S., G. Rasmussen, P. Snilsberg, C.E. Amundsen and T. Westby, "Assessing Toxicity and Mobilization of Impregnation Salts at a Contaminated Site", Fresenius J. Anal. Chem., Vol. 354, 1996, pp. 676-680.

[21] García-Valcárcel AI and Tadeo JL, "Evaluation of Laboratory Assays for the Assessment of Leaching of Copper and Chromium from Ground-Contact Wood", Environ Toxicol Chem., Vol. 26(10), 2007, pp. 2115-21.

[22] Ponizovsky AA, S. Thakali,H.E. Allen , D.M. Di Toro and A.J. Ackerman AJ, "Effect of Soil Properties on Copper Release in Soil Solutions at Low Moisture Content", Environ Toxicol Chem., Vol. (3) , 2007, pp. 671-82.

[23] Zhang MK and YP Xia YP, "Release Behavior of Copper and Zinc from Sandy Soils", J. Environ. Sci. (China), Vol.17(4) , 2005, pp.566-71. 


\title{
جفاف التربة وتأثيرها على حركة مركبات النحاس السامة
}

\author{
حسام الطاهر 1²، أندريا ديترنش² ، جون نوفاك2 \\ 1 قسم تقنية الهنسة الكيميائية، كلية ينبع الصناعية، الملكة العربية السعودية

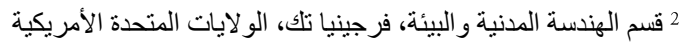

يتم استعمال مركبات النحاس السامة مع كثير من المحاصيل كمبيد للفطريات و البكتريا ومن أمثلة هذه الدحاصيل نبات الطماطم الذي يتم استزر اعه في الصوب الزر اعية ـ ولهذا فقد أجريت دراسة معملية لتحديد الميكانيزم الذي يتحرك به مركبات النحاس خلال التربة حتى يصل إلى الطبقات السفلى منها ـ تم اختيار نسبة الكربون الكلية الموجودة في التربة وجفاف التربة مع الدورة الحرارية التي يتم بهاهذا الجفاف بالإضافة إلى المحتوى المائي للتربة كعناصر للاراسة. وقد أجريت دراسة هذه العناصر بالطريقة المستمرة والطريقة المتقطعة ـ أظهرت النتائج أن حركة النحاس خلال التربة كانت مرتبطة بحركة المو اد العضوية في التربة. كما أظهرت النتائج أن جفاف التربة له تأثير حيوي على حركة كل من المركبات العضوية ومركبات النحاس ـ فقد كان تركيز النحاس الخارج من أعمدة محتوية على تربة جافة حوالي 120 ميكروجرام / لتر. وكان تركيز النحاس و الكربون الكلي الخارج من العمود المحتوى على تربة جافة أعلى بحو الي 20 مرة من الخارج من تربة رطبة. 